\title{
The Pro and Con of Written Corrective Feedback
}

\author{
Suhartawan Budianto \\ Faculty of Letters \\ University of Dr. Soetomo \\ Indonesia \\ hartawanbudi76@gmail.com
}

\begin{abstract}
Being the controversial issues leads written corrective feedback into two different arguments that written corrective feedback is plausible for ESL and EFL learners or it does not bring significantly for ESL and EFL learners. Through the debate, there are two queries revealing; what to do and where to go. Finally, it can be concluded that an effort to assist learners improving their accuracy of ESL and EFL writing has to be conducted by a teacher, and corrective feedback is one of the alternative techniques among others to make the learning outcome better. Moreover, both the local and global aspects are to be corrected and treated proportionally meaning the written corrective feedback not only concerns with local aspects but also with global aspects as well. Later, it would be better to evaluate long term effect of providing WCF on other occasions (a month or a semester after WCF given).
\end{abstract}

Keywords-written direct corrective feedback; indirect corrective feedback

\section{INTRODUCTION}

EFL issues to facilitate English learners to be good at EFL writing due to the fact that EFL writing is difficult for most EFL learners have been studied by many researchers. Learners are supposed to comprehend not only the form but also the content. The form represented by local aspects which consist of vocabulary, grammar, and mechanics while the content represented by global aspects is regarded as ideas, content, and organization [1].

As known, writing is hard to for most people, it does not matter what language is used (L1, L2, and a foreign language). Writing is not only difficult for most people but also for some successful writers [2]. In addition, "Reference [3] argues that writing is a strange activity”. Definitely, using a foreign language like English in the context of EFL writing is more difficult than L1 for most people where English is not the official language. Anyone who wants to study in higher level like university, generally will be required to be able to write particular essays. For students in English Department, EFL writing is one of compulsory course. To support the academic achievement, a good skill in writing essay is needed by most students, particularly those who are involved in higher level of education [3]-[7].

It is true that many EFL writers in the university level have many problems in the local aspects and global aspects to produce a good essay. This occurs because EFL writers not only need a good ability in using the local aspect but also the global aspects. Sometimes, some EFL writers are good at using the local aspects but they are poor at using global aspects or vice-versa. Moreover, there are still many EFL writers making errors both in local and global aspects which need to be corrected appropriately. Generally, EFL writers in elementary level usually make errors in local and global aspects while EFL writers in intermediate and advanced level make less error in local and some errors in global. "Reference [8] argues the test writer in elementary level will be treated far more tolerant than intermediate and advanced levels". As the intermediate and advanced learners, the university students in English Department are expected to produce a good quality in EFL writing both in local and global aspects.

The other aspect which must be regarded is a consistency. A consistency in giving CF never gets much attention in previous research. The previous research only emphasizes on the effectiveness of CF and how it is conducted by teachers. Teachers of L2 have to be alert that applying CF won't be very beneficial to students' L2 improvement if it is prepared, planned and implement consistently.

Looking insight EFL writing and error treatment, corrective feedback on local and global aspects of writing is certainly plausible. The term 'feedback' known as written corrective feedback (WCF) functions to refine and correct a learner' error both in global and local aspect errors inasmuch as error is not a trivial matter in EFL writing. Written corrective feedback is expected to improve the quality of EFL writing where teachers indicate the errors and help to correct the errors properly. If those errors are not shown and corrected appropriately, EFL writers are not aware that they have made errors in their writing.

The errors are usually made by EFL writers which they are not aware due to their low proficiency level. This clearly occurs since there are some different local aspects (vocabulary, grammar, and mechanics) but also global aspects (content, and organization) between L1 and a foreign language (English). The query raises how the errors have to be corrected. To answer this, it is necessary to examine the previous studies of providing corrective feedback in ESL/ EFL writing. 


\section{DISCUSSION}

Since 1980's, many studies on corrective feedback have been conducted and it has been a controversial issue up to now that is contributes positive or negative effects for EFL learners and ESL learners. It leads to a positive effect because corrective feedback can improve the language gains [1], [9][20]. On the other hand, error correcting is not good if it only emphasizes on grammar errors, even though it can be given by selecting some certain types of grammar targets [21]. [22] conclude that "improvements made during revision are not evidence on the effectiveness of correction for improving learners' writing ability".

Similar studies state that corrective feedbacks do not improve L2 learners' competence. The improvement during revision in the first draft is not guarantee that L2 learner will do the better on the subsequent writing. It is not very fair to focus on error to see the quality of L2 learners' writing [22], [23].

It is easy to claim that learners' writing ability improves because learners merely can revise their subsequent writing after having teacher's written corrective feedback. [22] argue that improvements made during revision are not evidence on the effectiveness of correction for improving learners' writing ability.

Moreover, [24] warns us that "a focus purely on errors is misleading as it does not reveal language gains”. [24] reports there are no relations between the second errors and the errors corrected in the first writing made by the learner. It is concluded that the effect of correction on subsequent writing is not proved since the errors in the second draft are not related to the errors corrected in the first draft.

Written corrective feedback examining the effectiveness, fluency and accuracy on L2 learners' writing have been carried out [1], [9]-[13], [15]-[20]. The previous studies also report that by having WCF, L2 learners not only gain the accuracy on one writing occasion but they can keep the accuracy on the other similar occasion [9]-[13].

Types of corrective feedbacks such as selective error correction [21], errors underlined corrective feedback, uncoded corrective feedback [22], and oral form-focused instruction [10] have been investigated in study of L2 writing.

Some corrective feedbacks such as direct corrective feedback, meta-linguistic corrective feedback, and oral formfocused instruction corrective feedback have been used in study of L2 writing [9]-[14], [23], [25] while indirect corrective feedback has been also applied in L2 writing [13], [25], [26].

It does not matter what level of proficiency, corrective feedback is beneficial not only the high proficiency L2 learners but also low proficiency L2 learners in their writing, [9]-[14], [24]-[25].

Investigating grammatical and lexical errors, reference [14] found that the direct corrective feedback on direct correction and simple underlining of errors are significantly superior to describing the type of error. Direct correction is best for producing accurate revisions, and students prefer it because it is the fastest and easiest way for them as well as the fastest way for teachers over several drafts. Then, reference [14] concludes that students feel that they learn more from self-correction, and simple underlining of errors takes less teacher time on the first draft.

Teachers think that corrective feedback is very important to improve L2 learners' competence and students suggest that they need not only corrective feedback but also more comments from the teachers about their writing [1], [15]-[20].

The other aspects of writing are attempted to explore by other studies. They examine students' respond and teacher belief of WCF. Investigating other components of WCF shows that teachers' beliefs are very prominent in conducting WCF [16]-[18]. However, there are still some gaps between teachers' beliefs and written feedback practice. For example, teachers mark errors comprehensively although selective marking is preferred [17].

Furthermore, teachers' self-assessment and students' perception about WCF can't be separated. The relationship between teachers' self-assessment and student perceptions of teacher-written feedback is very strong [1]. The problem is that most teachers are not totally aware of local and global issues [1], [16]. In short, many people focus to give corrective feedback on local aspects (language use, vocabulary, and mechanic) while global aspects (content and organization) do not get much attention.

The role of corrective feedback is not only prominent in determining whether someone passes the writing course or not, but also in contributing to the learners' language gains. Without a concern to the role corrective feedback given by the teachers or lecturers, the function of corrective feedback is only used to pass writing examination. In investigating the role of corrective feedback in writing thesis, [27] remind the crucial role of feedback in postgraduate thesis examination practice. [27] state that "without feedback, there is no little impetus for the candidate to progress, to close the gap between current and desired performance, and to attain the level needed to become a member of the scholarly community”.

Relating to selecting error categories, some studies use focused corrective feedback; simple past tense and the definite article [9]-[11]. It is called focused WCF because there are only one or two linguistic features investigated. Unfocused WCF is applied by [4] in which there are twenty-three types of errors. L2 writing teachers should be alert what linguistic features that are more treatable but less teachable since there will be more effective to give the corrective feedback which relate L2 learners' prior knowledge. For example, giving corrective feedback on the use of articles in writing for elementary students is less teachable. This is done to ensure the effectiveness of WCF which contribute the language gains for L2 learners.

Selecting errors category usually relies on the characteristics of participants indicating the L1 and L2 owned by participants. The participants from the previous studies may come from the same L1 background [16]-[18], [24] or different L1 background [9]-[14], [16]-[18], [26]. Having the participants from the same L1 background has an advantage in examining the most difficult linguistic errors. The participants 
from the same L1 background generally make the same error categories e.g. the use of tenses, article, countable and uncountable nouns, etc. Therefore, the researcher could be able to determine what error categories should be provided by WCF. On the other hand, having participants from the different L1 background needs some consideration because of the varied of L1 background. Let's compare L2 learners with French and Dutch as L1 background with L2 learners with Chinese, Japanese, and Indonesian as L1 background.

As proposed by [28], there are two important components of doing written corrective feedback: (1) strategies, and (2) students' responses. Here, strategies deal with direct, indirect or meta-linguistic feedback while students' responses relate to revision required, and attention to correction only required. The most crucial statement is that there is no ideal method in executing corrective feedback (There is a weakness and strength of any WCF). [29] states no corrective feedback recipe. In addition, he also argues that the success of conducting corrective feedback relies on classroom situation, kinds of error learners produce, levels of proficiency, kind of writing, and accumulation of other unknown variable. Corrective feedback would be more valuable if there is an improvement in both language fluency and accuracy. [29] explains that there are two objectives in providing corrective feedback"; (a) to gain the language accuracy and (b) to gain the language fluency. Accuracy relates to the local aspects of writing while fluency deals with global aspects of writing.

\section{CONCLUSION}

Due to becoming the controversial issues, finding conflicting results, and raising different point of views WCF emerges as a challenging and relevant topic to discuss in ESL writing. Accordingly, there are still few gaps which must be investigated to come to the conclusive proposition. It is believed that the main goal of corrective feedback is to improve students' quality of EFL writing for future achievement or long-term effect even though some studies only have investigated the short-term effect.

However, it is not wise to allow learners make error in L2 and EFL writing without any strategies to help them. EFL writers commonly make errors, but allow the students to make errors is something weird for a teacher. Abandoning to give error correction is not a wise solution, but finding the way to correct the errors is the most relevant issue.

In short, those previous studies showing the significant effect of WCF can be classified into three different targets of using WCF; (a) examining the accuracy, (b) investigating the teachers' and students' perception, and (c) the other aspects of writing. Most of the previous studies focus on the local aspects (linguistic accuracy) as the target of providing WCF while global aspect has not been investigated a lot.

There should be a careful consideration of using certain linguistics features, called focused feedback in WCF. For example, the focused feedback given on two functional English articles and simple past are not sufficient to determine linguistic accuracy overall since the other L2 features should be treated equally. No matter the level of participants' proficiency, providing the different types of corrective feedback always leads the better outperformance than without corrective feedback.

Assisting learners to improve their accuracy of L2 writing has to be conducted by a teacher, and corrective feedback is one of the alternative techniques among others to make the learning outcome better. What to remember is that corrective feedback helps ESL/EFL learners to improve L2 writing quality since corrective feedback is not only giving learners the correct local aspects but it also expects the learners to use the appropriate global aspects.

It is definitely believed that the debate between two contradictory ideas "To correct or not to correct" arrives to the more appropriate statement saying what to correct and how to correct" [29]. The first answer is both the local and global aspects are to be corrected. The second answer is the local and global aspects must be treated proportionally meaning the written corrective feedback not only concerns with local aspects but also with global aspects as well. In local aspects, a teacher selects the errors (the use of articles, verb tense, spelling etc.) that will be corrected because it will be very hard for the teachers to correct every error in L2 writing. Moreover, L2 learners will be very frustrated because there are many errors shown by their teachers. The teachers spend much time only for correcting errors they do not consider the improvement of other aspects of L2 writing such as content and organization. Consequently, selecting error that will be corrected is needed to give teachers time to consider the other aspects in EFL writing (content and organization).

The effectiveness of providing corrective feedback might be seen from the sustainability of how long the study is conducted and how long the ESL/EFL learners can retain the writing quality after corrective feedback given. In short, the length of WCF studies is very varied based on the consideration of investigating the effect; short or long term effect. One interesting goal from the previous study is that how long learners can keep the linguistic targeted if experimental study is used. In experimental study, the short term effect as objective is more appropriate than long term effect. The effect will be seen directly after the treatment (WCF). Later, it would be better to evaluate long term effect of providing WCF on other occasions (a month, semester after WCF given). The effect of WCF might be seen directly after WCF is given on subsequent student writing. Further, the effect of WCF might also be seen overtime in the future (e.g. in the end of the semester or in the end of the year) after corrective feedback is given. The effects of learning outcome are more popular with so-called "short-term effect "and "longterm effect”.

\section{REFERENCES}

[1] J. L. Montgomery and W. Baker, "Teacher-written feedback: Student perceptions, teacher self-assessment, and actual teacher performance," J. of Secon. Lang. Writ., vol. 16, pp. 82-99, 2007.

[2] G. Taylor, A Student's Writing Guide. How to Plan and write Successful Essays. UK: Cambridge University Press, 2009. 
[3] N. Warburton, Nigel. The Basic of Essay Writing. London and New York: Routledge.

[4] B. Greetham, How to write Better essay. New York: Palgrave Macmillan, 2001.

[5] K. McMillan and J. Weyers, How to Write Essays \& Assignments. Essex: Pearson Prentice Hall, 2010.

[6] D. Shiach, How To Write Essays. United Kingdom: Oxford, 2009.

[7] S. C. Weigle, Assessing Writing. UK: Cambridge University Press, 2009.

[8] J. B. Heaton, Writing English Language Tests. New York: Longman, 1990.

[9] J. Bitchener, S. Young, and D. Cameron, "The effect of different types of corrective feedback on ESL student writing,” J. of Secon. Lang. Writ., vol. 14, pp. 191-205, 2005.

[10] J. Bitchener and U. Knoch, "The value of written corrective feedback for immigrant and international students,” J. of Secon. Lang. Writ., vol. 19, pp. 207-217, 2008.

[11] J. Bitchener, "Measuring the effectiveness of written corrective feedback: A response to 'Overgeneralization from a narrow focus; A response to Bitchener (2008)',’ J. of Secon. Lang. Writ., vol. 18, pp. 276-279, 2009.

[12] J. Bitchener and U. Knoch, "The Contribution of written Feedback to Language Development: A Ten months Investigation,” Appl. Lingu., vol. 31, no. 2, pp. 193-214, 2009.

[13] J. Bitchener and U. Knoch. "Raising the linguistic accuracy level of advanced L2 writer with written corrective feedback," J. of Secon. Lang. Writ., vol. 19, pp. 207-217, 2010.

[14] J. Chandler, "The efficacy of various kinds of error feedback for improvement in accuracy and fluency of L2 student writing," J. of Secon. Lang. Writ., vol. 12, pp. 267-296, 2003.

[15] N. W. Evans, K. J. Hartshorn, R. M. McCollum, and M. Wolfersberger, "Contextualizing corrective feedback in second language writing pedagogy,” Lang. Teach. Res., vol. 14, no. 4, pp. 445-463, 2010.

[16] I. Lee, "Student reactions to teacher feedback in two Hong Kong secondary classrooms,” J. of Secon. Lang. Writ., vol. 17, pp. 69-85, 2007.

[17] Lee, Icy. 2008. Understanding teachers' written feedback practices in Hong Kong secondary classrooms. J. of Secon. Lang. Writ. 17, 144-164

[18] I. Lee, “Ten mismatches between teachers' belief and written feedback practice,” ELT J., vol. 63, no. 1, January 2009.

[19] K. Lundstrom and W. Baker, "To give is better than receive. The benefits of peer review to the reviewer's own writing," J. of Secon. Lang. Writ., vol. 18, pp. 30-43, 2009.

[20] C. Vasquez and J. Harvey, "Raising teachers' awareness About corrective feedback through research replication,” Lang. Teach. Res., vol. 14, no. 4, pp. 421-443, 2010.

[21] J. Truscott, "Selecting Errors for Selective Error Correction," Stud. in Engl. Lit. and Ling., pp. 93-108, 2001.
[22] J. Truscott and A. Y. Hsu, "Error correction, revision, and learning," J. of Secon. Lang. Writ., vol. 17, pp. 292-305, 2008.

[23] A. Bruton, "Designing research into the effect of grammar correction in L2 writing; Not so straightforward,” J. of Secon. Lang. Writ., vol. 18, no. 136-140, 2009.

[24] A. Bruton, "Vocabulary learning from dictionary referencing and language feedback in EFL translational writing," Lang. Teach. Res. vol. 11, no. 4, pp. 413-431, 2007.

[25] C. G. van Beuningen, N. H. de Jong, and F. Kuiken, "Evidence on the Effectiveness of Comprehensive Error Correction in Second Language Writing,” A J. of Res. in Lang. Stud., vol. 62, pp. 1-14, 2012.

[26] D. R. Ferris, H. Liu, A. Sinha, and M. Senna, "Written corrective feedback for individual L2 writers,” J. of Secon. Lang. Writ., vol. 22 pp. 307-329, 2013.

[27] V. Kumar and E. Stracke, “Examiners' reports on theses: Feedback or assessment?” J. of Engl. for Acad. Purpos., vol. 10, pp. 211-222, 2011.

[28] R. Ellis, “A typology of written corrective feedback types,” ELT J., vol. 63, no. 2, April 2009

[29] D. Guenette, "Is feedback pedagogically correct? Research design issues in studies of feedback in writing,” J. of Secon. Lang. Writ., vol. 16, pp. 40-53, 2007.

\section{ABOUT THE AUTHOR}

Suhartawan Budianto is an English Lecturer at the Universitas Dr. Soetomo in Indonesia. He earned his Doctorate degree in 2017 from Universitas Negeri Malang, East Java Indonesia on English Education. His research interests are mostly on writing and speaking. He has published several articles on writing, speaking, and applied linguistics. E-mail: hartawanbudi76@gmail.com. Cell phone: 081553340807. Some of his published articles are (1) Using Chain Story to Improve Junior High School Students' Ability in writing Narrative. Jurnal Sastra \& Budaya (DINAMIKA) ISSN: 2337-8905 Vol 1No.2 (2) The use of Worksheet Entry Form (WEF) of Corrective Feedback to Improve Students' Speaking Ability. Enrichment of Career by Knowledge of Language and Literature I, ISBN: 978-602-0917-00-9 (3) The Role of Written Corrective Feedback in EFL writing. Enrichment of Career by Knowledge of Language and Literature II, ISBN: 978-6029494-75-4 